\title{
快適なねごこちを得るための寝具の条件
}

南本珠已

1.はじめに

快適なねどこちを得るうえで寝具の果たす役割は大き く，ねごこちのよい復具を用いることが必要であること はいうまでもない。

一般に考えられているねごてちのよいふとんの条件に は，誛床内の温湿度を快適に保ち，䁃返りがうちやすく， 肌沿いのよいととなどがあげられている1)。しかし，実 際にはそれらの条件がすべて満たされていてす，よいね でこちが得られるとは限らない。なぜならば,ねごこち のよし悪しは，個々人が長い年月をかけて作ってきたふ とんに関わる習慣や，好みによって決定されるてとが多 く, 単に温熱生理的・運動機能的な要求を満たしている だけでは，要求されている好みを満足させるようなねご こちとはいえないからである。また，眠る人間の側が体 調を崩していたり，精神的な波労やストレスを感じてい たのでは安眠はできないし，寝室の環境が温度や湿度，
静けさ，照明，スペースといった条件を満たしていない 場合や ${ }^{2 \sim 4)}$, 室温の変化に応じた適切なふとんの用い方 がなされていない場合にも，熟睡感を得るととはできな い。

てのように，快適なねごこちに関する要因には，1. 精 神的・身体的要因，2. 寝室環境江関する要因，3. 夏具 の機能そのあのに関する要因などがあり ${ }^{1)}$ ，てれらは相 互に関連しあうあのといえる。したがって，人か㹟道な 眠りを得るためには, 寝具の機能だりを追求するので なくて，それを使う人の好みや生活習慣を考慮に入れ， さらに室温に応じて寝具を組み合わせるととが必要とな る。

そこで本稿では, 当研究所が行った首都圈 53 家庭の 寝室環境之寝具の使用実態調查, および現在市場にみら れるふとん（表 1)を用いた時の寝床気、候の測定結果侸 づきながら゙，快適に眠るための㤥具の条件を，朖具と 寝室環境のバランスから具体的に述へたいと思う。

表 1 試 料

\begin{tabular}{|c|c|c|c|c|c|c|c|}
\hline 種 & 類 & 中わた素材 & 側 生 地 & 中わた重量 & 総 重 量 & 厚 & \# \\
\hline \multirow{3}{*}{$\begin{array}{l}\text { 卦 } \\
\delta_{2} \\
亡 \\
h\end{array}$} & 綿 & 綿 $100 \%$ ( JIS 特級) & 綿サテン & $4.5 \mathrm{~kg}$ & $5.2 \mathrm{~kg}^{*}$ & $6.1 \mathrm{~cm}^{*}$ & $\begin{array}{l}\text { 側 } 155 \times 200 \mathrm{~cm} \\
\text { 仕上がり } 145 \times 189 \mathrm{~cm}^{*}\end{array}$ \\
\hline & 羽毛 & $\begin{array}{l}\text { ホワイトグース } \\
\text { (ダウン率 70\%) }\end{array}$ & $\begin{array}{l}\text { 綿サテン } \\
\text { (目つぶし加工) }\end{array}$ & $1.4 \mathrm{~kg}$ & $2.6 \mathrm{~kg}^{*}$ & $16.6 \mathrm{~cm}^{*}$ & 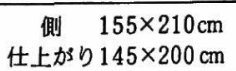 \\
\hline & 合緎 & ポリエステル $100 \%$ & 綿サテン & $1.8 \mathrm{~kg}$ & $2.5 \mathrm{~kg}^{*}$ & $8.3 \mathrm{~cm}^{*}$ & $\begin{array}{c}\text { 側 } 150 \times 196 \mathrm{~cm}^{*} \\
\text { 仕上がり } 145 \times 190 \mathrm{~cm}^{*}\end{array}$ \\
\hline \multirow{3}{*}{$\begin{array}{c}\text { 僌 } \\
\delta \\
亡 \\
h\end{array}$} & 綿 & $\begin{array}{l}\text { 綿 } 95 \% \\
\text { レーヨン } 5 \%(\text { JIS 1 級) }\end{array}$ & 綿サテン & $6.0 \mathrm{~kg}$ & $6.5 \mathrm{~kg}^{*}$ & $11.8 \mathrm{~cm}^{*}$ & $\begin{array}{c}\text { 側 } 103 \times 200 \mathrm{~cm} \\
\text { 仕上かり } 98 \times 190 \mathrm{~cm}^{*}\end{array}$ \\
\hline & 羊毛 & ウール 100\% & $\begin{array}{ll}\text { 表 } & \text { 綿ニット } \\
\text { 裹 } & \text { 綿サテン }\end{array}$ & $2.5 \mathrm{~kg}$ & $3.5 \mathrm{~kg}^{*}$ & $6.0 \mathrm{~cm}^{*}$ & $\begin{array}{c}\text { 側 } 110 \times 220 \mathrm{~cm} \\
\text { 仕上がり } 100 \times 200 \mathrm{~cm}\end{array}$ \\
\hline & 混紀 & $\begin{array}{l}\text { 綿 } 70 \% \\
\text { ポリエステル 30\% }\end{array}$ & 綿サテン & $6.0 \mathrm{~kg}$ & $6.5 \mathrm{~kg}^{*}$ & $13.9 \mathrm{~cm}^{*}$ & $\begin{array}{c}\text { 側 } 103 \times 200 \mathrm{~cm} \\
\text { 仕上がり } 95 \times 190 \mathrm{~cm}\end{array}$ \\
\hline
\end{tabular}

*は㬰測値，その他は表示の通り

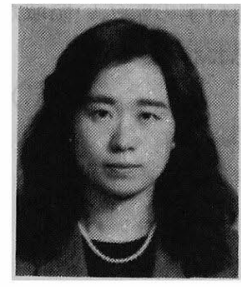

Requirements of the Futon for Comfortable Sleep

筆者紹介 TAMAMI MINAMIMOTO, Consumer-Goods Research Institute, 商品科学研究所 研 究部 研究員

筆者は，西武セゾングループの商品科学研究所で寝具類の研究に従事しておられる若手研究者である。

本稿では，快適なねごてちを得るための寝具の条件，寝具と演室環境のバランスを中心に，使用者の子 とんに関する好みや習慣,ライフスタイルなどを総合的に解説していただいた。 


\section{2. 零具の機能と室室㻴境}

らとんに求められる性能を睡眠の生理からみると，ま ず，段床内を適切な温度に保つために必要な保温性があ げられる。鲢眠中は人体の新陳代謝が低下するため，寝 床内の温度を保ち，体温を保持しなければならない。そ てて，ふとんの性能としては，ふとん自体の保温生のよ さと、滞床内の暖かさを逃がさないような肌沿いが必要 となる。保温性とならんで重要なのが, 寝床内の湿度を 調節する性能である。相眠中であ不感蒸泄は絶えず行わ れており，また，汗をかきやすくなることから゙，漫床 内の湿度は高くなりやす心。とのため，ふとんには吸湿 性・透湿性・放湿性加基本的な性能として要求される。

その他，挂々とんは体にかかる負担が少なく，肌沿い がよいとと，敷るとんは適度なかたさがあり，体が沈ま ず䝿返りのうちやすいととなど，人間工学的にも条件を 满たしていることが望まれる。

一方，德室環境であるが，我が国の場合四季の移り変 わりがはっきりし，年間の寒暖の差の大きいととが特徴 といえる。それを補うために掵暖房器具の普及はかざま しく, 社団法人 日本電機工業会の調查によれば, 昭和 60 年3月の時点での冾暖屏兼用型のルームエアコンの 普及率は52.3\%に達したと報告されている。しかし，寝 室での命暖房器具の普及率はそれほど高くなく，その使 い方けとんどの人が「留る前に使用し，寝る時に切る」

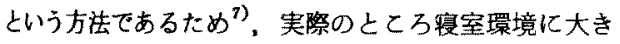
な改善は認められないようである。

したがって，一般家庭での蔓休気候の調節は依然しし てふとんに負うところが大きく，実際にはふとんの組み

表 2 季節別にみた代表的なるとんの組み合わせ

\begin{tabular}{|c|c|}
\hline 秉穊 & 安 具 0 種 類 \\
\hline 春 & 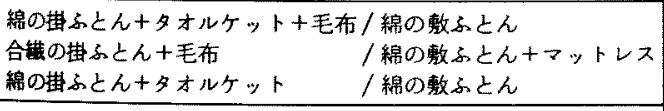 \\
\hline $\begin{array}{l}\text { 梅 } \\
\text { 雨 }\end{array}$ & $\begin{array}{l}\text { /綿の教ふとん+マットレス } \\
\text { /綿の敖ふとん } \\
\text { / 綿の敷ふとん }\end{array}$ \\
\hline 夏 & $\begin{array}{l}\text { /綿の敖ふとん } \\
\text { /綿の敖ふとん+マットレス } \\
\text { /混紀の数ふとん }\end{array}$ \\
\hline 政 & 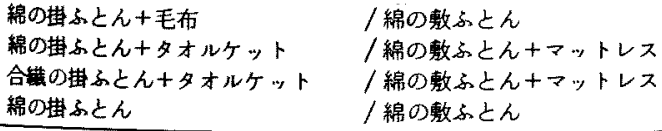 \\
\hline 冬 & 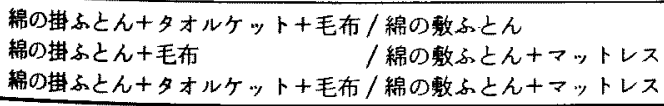 \\
\hline
\end{tabular}

・組み合わせ住䐓不同
合わせ万によってエ夫されていると予想される。そてで， 家庭でのふとんの用いられ方を調へ，表 2 に季䬦を代表 する期ふとんと敷ふとんの組み合わせ方をまとめた。そ の結果, 組み合わ甘方が, 室温の変化と対応するように 変わっていくのは墳ふ上ん側で，僌ふとん側は使用する 枚数などに，好みや習慣の影䇾がみられた。年間の室温 変化とふとんの組み合わせ力をみると，人は温度の変化 に比較的敏感侄対応しており，毛布やタオルケットなど を補いながら，寝床内の温度を微調整していることがわ かる。それだけに，室温に応して適切にふとんを組み合 わせているかよ゙うかが，快適なるでこちを得るための鍵 となっていると考えられる。

以上のようなとと加ら, 室温の変化季節の変化とし てとらえ直し，季節でとに，ふとんに要求される性能と 室温に応じた組み合わせ方を明らかにし，仭適なねごこ ちを得るための条件を検討していくとととする。

\section{3. 秄節と家具}

\section{1 夏}

夏は他の季節のように，呾具で块適な覀床気候を作る ことが難しい。前述したように，寝室を朎房する人はい まだ少なく，また，冷房を入れても終夜使用する人が少 ないととすあって，夏の夜は誛苦しく，調査の結果では 約半数の人が譻床内を「暑いと感じていた。暑さに慣 れていることああって，入休時に誛床内が快適と感じら れる時の窒温は約 $27^{\circ} \mathrm{C}$ て， $28^{\circ} \mathrm{C}$ 以になると「暑い しいう申告が増えてくる。特に, 起床時の室温が $28.5 \mathrm{C}$ 以上の場合には，十分な熟睡感を得られないととが多か った。一方，ふとんの組み合わせ方をみると，中わたの 入ったふとんは室温が $24 \mathrm{C}$ 以上になると用い られなくなり，室温が26〜27 Cになるとタオ ルケット1枚の人が王倒的に多くなった。また， 票ふとんの使用枚数は，室温が $27{ }^{\circ} \mathrm{C}$ 以上になる と1枚に減らす人が増加し，習慣に真うところ 加大きく，使用状況に变化の少ない敷ふとんの 用い方にあ動きがみられた。

こういった㖟室環境下で用いるふとんには， 熱加こあらず，吸湿性・透湿性・放湿性を具備 しているものが望まれる。図1は僌ふとんの德 床内温度を，図 2 は敷ふとん加ら床への放湿量 をみたあのである。羊毛の敷ふとんは，従来の 綿や浘紀の教ふとんの1/20厚さしかないとと もあって，放熱性・透湿性に優れていることが わかる。一方，吸湿性が最も優れているのは綿 のふとんで,シーッ下の湿度を他より娄低く保 つととができる。夏は発汗量が多いため，吸湿 
性は欠かすことのできない性能である。吸湿性を維持す るためにも夏は頻繁にふとんを干し，よく乾燥させる必 要がある。

以上，夏のふとんに望まれる条件を述べてきたが，夏

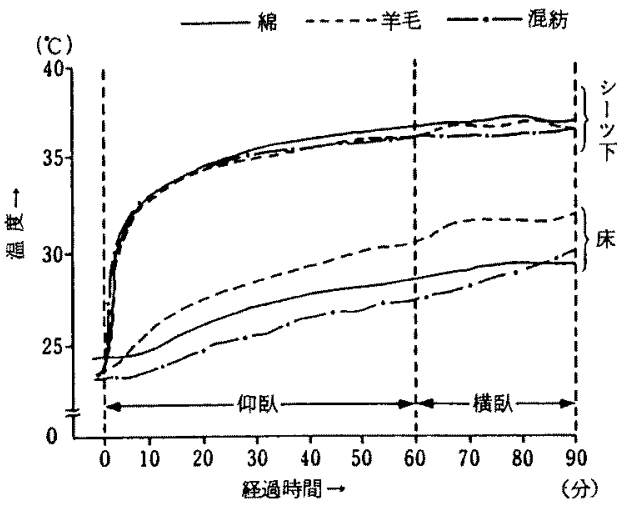

図 1 漫床内温度(敷ふとんの比較)

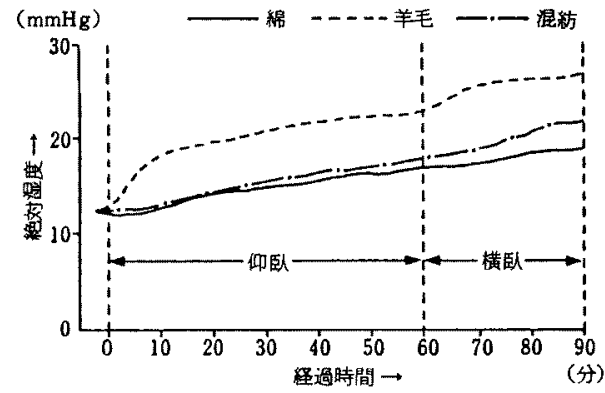

図 2 床の湿度(敷ふとんの比較)
の快適な眠りには枕やシーツ・カバー・パジャマといっ たふとん以外の德装品の影暗も見逃せない。玌高さ， 大きさ，硬さか使用者の好みに合っているととに加え， 夏の場合にはむれにくいこよあ大切な要因となっている。 現在市場にみられる枕の中では，ソバガラが最も熱加と 6りにくく，半ソバは，ソバガラの比率の高い方がれ にくいと報告されている゙） また，シーツやカパー,パ ジャマなどは吸湿性のよい綿 100\%のあのが望ましく， シーツやカバーは汗をかいても肌にべとかない変わり

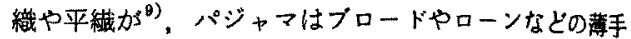
で目のつんだ布帛が，夏の素材として適している゙

\section{2 冬}

冬の代表的なふとんの組两合わせ方は，卦ふとん1放 に毛布やタオルケットを加えたすのである(表 2)。

入床時に德床内が快適と感じられる時の室温は $12 \mathrm{C}$ で，7〜10 Cの籁用では寒さを感じる人が增える。また， 起休時の室温が $8^{\circ} \mathrm{C}$ 以下になる状態では「熱䩾できなか った」という人が增えるため，入床時の室温は $12 \mathrm{C}$ 上, 起床時の室温は最低 $9^{\circ} \mathrm{C}$ 必要といえる。四3より, 㛜冬期の起床時の平均室温 $9^{\circ} \mathrm{C}$ の時，快適なれどちか 得られた組み合わせをみると，掛方とん 1 枚十毛布2故， または，挂ふとん2枚十毛布 1 枚となる。これを重量で みると，最む軽いのが羽毛系で $5.4 \mathrm{~kg}$ ，最も重いのが綿 柔で $7.8 \mathrm{~kg}$ となり，組み合わせによって体に加なりの角 担のかかっていることがわかる。ふとんの重さは個人の 好みの大きいものであるが，医学的にはあまり重いふと んを卦けることは好ましくないよされている。したがっ て，冬季の場合は，ふとんの組み合わせだけで寝床内を 快適に整えるよりあ，適当に寝室を䁔房して $12^{\circ} \mathrm{C} ら$

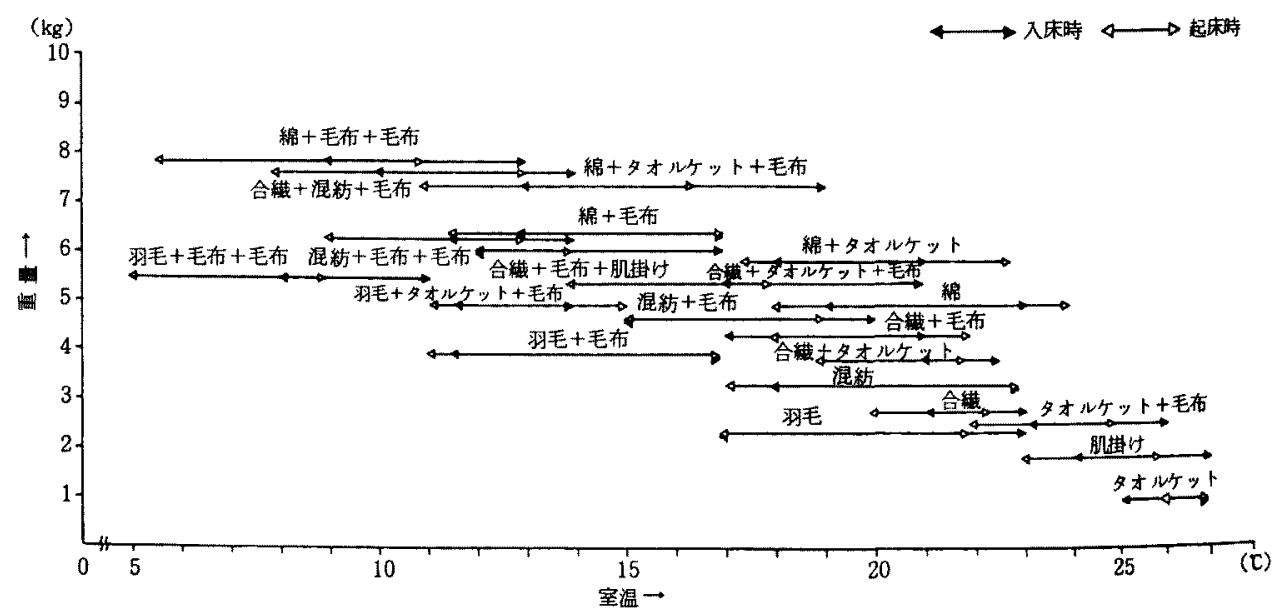

図 3 掛ふとんの組み合わせ方と重量および仭適室温範囲 

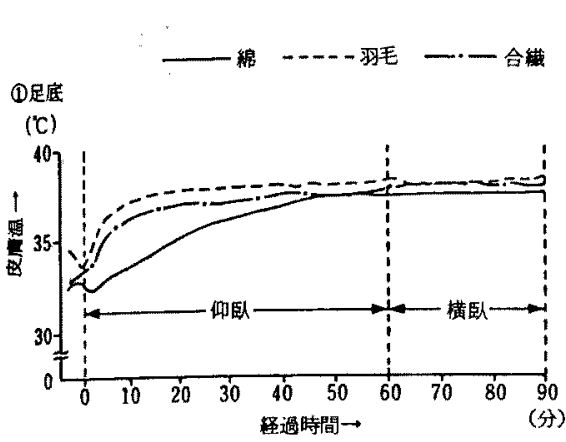

(2) 间

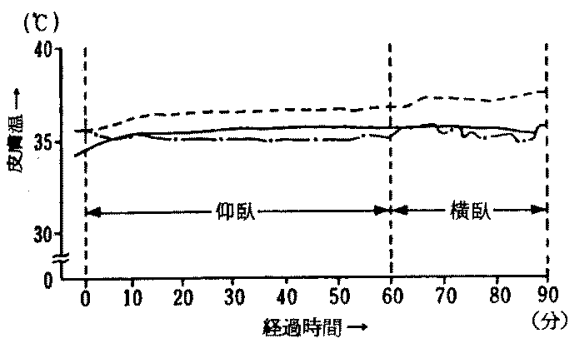

図4 期ふとんが皮有温におよぼす影響

い室温を請節するとと，また手足の皮膚温が低い人や 特に寒い地域では，あんかや電気毛布などを用いること なども考える方がよいといえる。

次に，冬の演具に望まれる性能であるが，第 1 にあげ られるのはやはり保温性である。図 4 は卦ふとんの寝床 内の温度変化が皮庵温におよ吉影響を, 綿, 羽毛, 合 絓の慗材別に比較したものである。

羽毛ふとんの場合, 入床後の温度変化が速いため演床 内が暖まりやすい。足底の温度は，入眠時に $29^{\circ}$ 以上に なるといわれている ${ }^{11)}$ が，羽毛ふとんは他に比へ足底の 温度上开汃速く，乙の点加らも籍冬期の入眠を助けてい ると考えられる。また，寝返りをうっても空気の流入が 少なく，肌洛いがよいため局口からの熱の逃げ方が少な いととも，寝床内を暖汃く保つ一因となっている。それ に対し，今回実験に用いたような一般的な規格のふとん では，綿や合䋐のふとんは羽毛ふとんより年熱絶縁抵抗

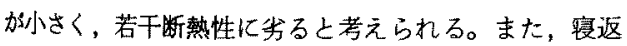
り後の周口からの熱の逃げ具合を，サーマルイメージャ 一でとらえると，綿や合織のふとんは有口にすきまかで き，暖まった空気の逃げている様子が認められるととか ら、綿や合織のふとんはあまり肌沿いがよくないとも考 えられる。

毛布やタオルケットを㭪うととなく，挂ふとん 1 枚だ けで使用できる室温範囲をみると，綿や合繊が 17 22
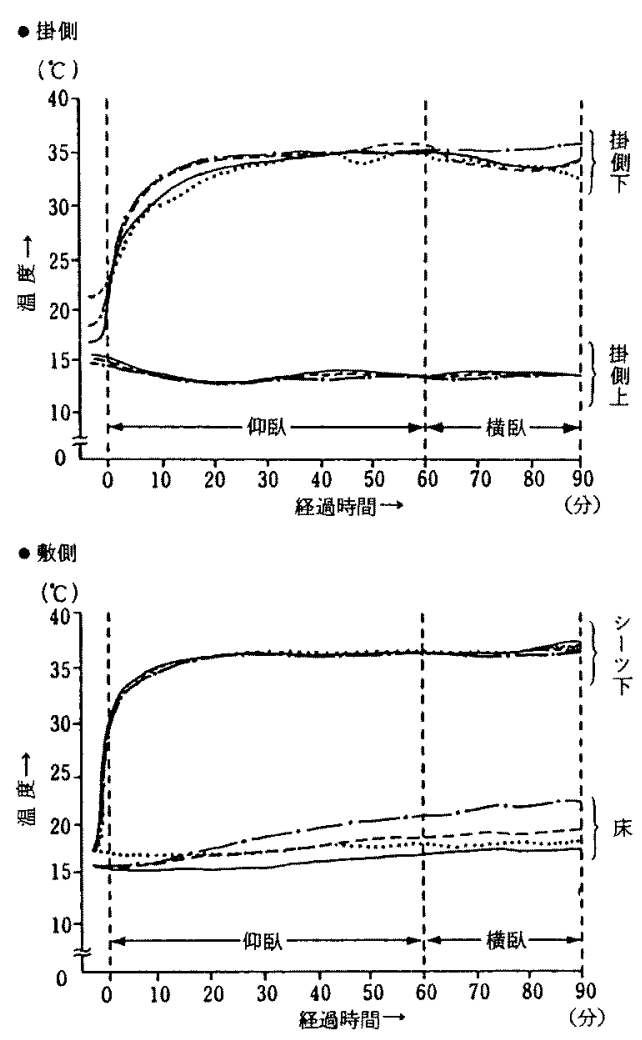

$$
\begin{aligned}
& \text { パターン1-綿の持ふとん+毛布十タオルケット/綿の兓ふとん } \\
& \text { 十マットレス }
\end{aligned}
$$

龱 5 漫床内温度

'Cの籍囲にあるのに対し，羽毛は15〜20 C と少し低め の温度まで対応でき，てれからあ羽毛ふとんは他に比へ 暖がてとがわかる。

以上のような性能を踏まえた上で，冬季における効果 的なふとんの組み合わせ方を考えると，最も暖かく，し 加あ軽く眠るためには，掛ふとん側に羽毛ふとんと毛布 を組み合わせ，敷るとん側はるとんを 2 枚重ねるのがよ

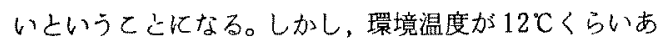
れば，綿や合蟣のふとんでも毛布やタオルケットを加え るとしによって, 羽毛と同じ程度の暖かさを得られるこ とが確認されており，暖かさの面だけをみるのであれば， 現在市場にみられるいずれのふとんでも，快適な机でて ちを得ることができる(图 5)。また，敷ふとん側に敷毛 
布やウインターシーツなど, 起毛したすのを用いること によって入床時の冷感触を取り除けば，寝床内はより暖 かく感じられる゙2。

\section{3 春 - 秋}

中間期は掛ふとんの用い万に個人差が目立ち，春と秋 を比べてもをの傾向は若干異なる。暑さ，寒さに対する 感覚は季節によって変動するものであり，こうした感覚 の変化から者衣状態に差が生じるように多，ふとんの掛 け方にも同様の傾向がみられる。たとえば, 室温が $20 \mathrm{C}$ になる 5 月と 10 月を比べると，5月は枚ふとん 1 枚に 毛布を加えることが多く，10月は毛布のかわりにタオ ルケットを加える人が多い。てれは衣服の場合と同様で, 春は厚着になる傾向があり，秋は薄着になる傾向がある ためととらえられる。この時の寝床内の温熱感をみると, 室温が 20 Cの時に「ちょうどよい」と感じる人が多く， 春は秋に比へ若干厚めにふとんを掛けているとともあっ て，22Cになる上「暑い」「やや暑い」が増え，秋は 17 C以下で「寒い」やや寒い」と感じる人が増えた。環 境温度の変化が大きく，快適と感じられる室温の範囲が 比較的狭い春と秋に対応するたかには，ふとんを1枚だ けで使用するのは限界があり，毛布やタオルケットなど を使って寝休内を砫調整する必要が生じると考えられ る。
春と秋の平均的な室温範囲からみると、羽毛らとんの 場合は，それ自体の保温性が大きすぎるお㻴境温度加 20 C以上になると汗をかきやすく，欴床内加高湿になり むれを感じやすくなるため，あまり使用に適さなくなる。 また，敷ふとんの場合は，室温が $17 \mathrm{C}$ 以下になると厚 さ $6 \mathrm{~cm}$ の羊毛の敷ふとん 1 枚では寒いと感じられるた め，あう1枚ふとんを補う必要牲しる。

以上のようなととから，春と秋のふとんに求められる 性能としては，他の复具と組み合わせて温度変化に対店 できるような，適度な暖かさが要求される。

\section{4. をとめ}

以上，快適なねどとちを得るのに必要な条件について， 誛具と漫室環境とのバランスを考えるという視点加迷 ペてきた。

しかし，いままで述へてきたようなふとんの性能は， ふとんを“眠るための道具”としてとらえた性能であっ て，てれは実際の生活の中で寝具に求められる事柄の一 部にすぎない。そこで最後に，暮らしの中かららとんを 考えるため，より広く“生活盰としてのふとん”という 視点も加えて，“快適なふとんライフ”の検討を行うこ ととする。

まず，生活者が望んでいるふとんの条件としては，

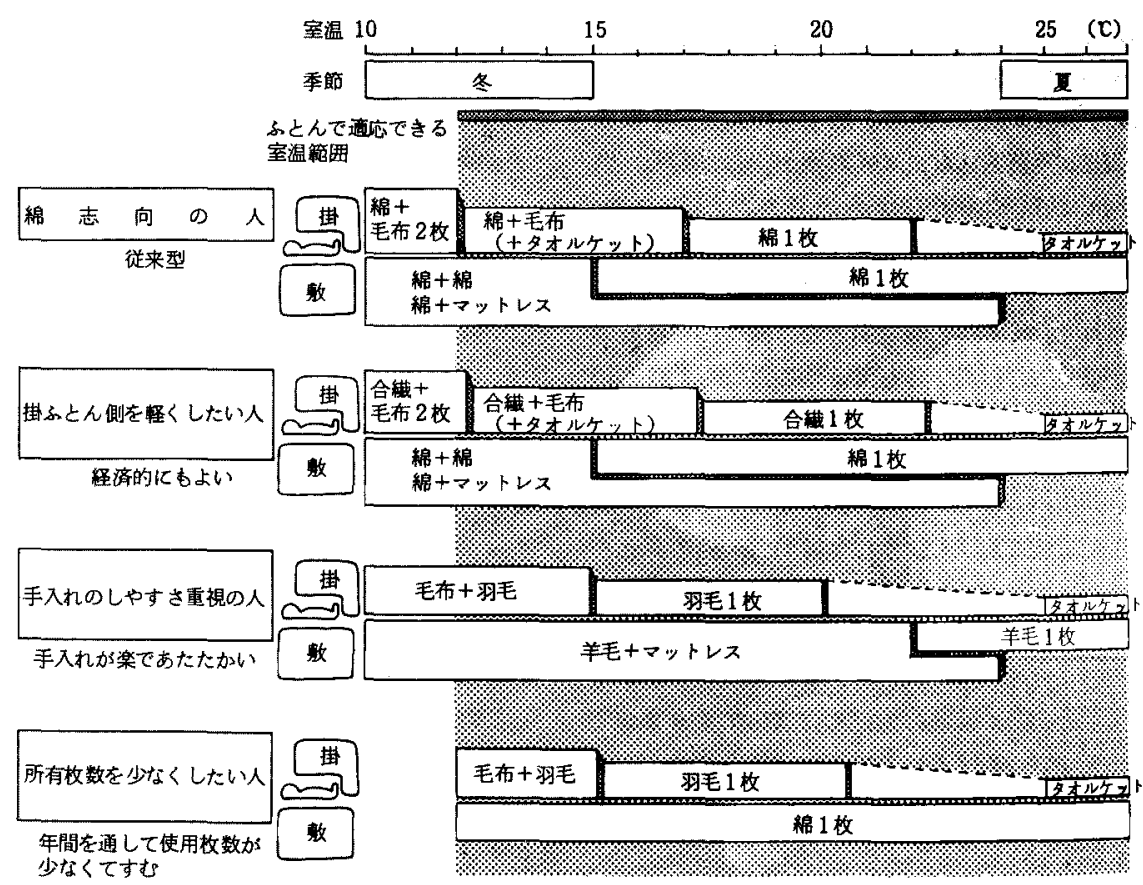


(1) 安眼できるこ上

(2) 每日の取り报いが楽なとと（ふとん自体が軽く，

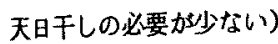

(3) 收納生がよく，できれば 1 枚で 1 年中使えること

(1) 打ち直しなど手間がはふらるとと

(5) ほてりがたたず衛生的でダニ・カビの心配がない 乙と

があげられる。ふとんは何といってす快通な眠りを提供 する6のであるから，「安眠できるもの」でなくてはな らない。しかし現代生活では，それとならんで、上げ下 ろしが楽で日常の管理が簡単なもの，所有枚数が少なく

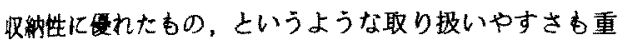
視されているととがわかる。双納スペースの少ない住宅 事情のもとでは，死葴化したふとんを抱えるはとんどの 家庭か，收納に頭を痛めている。また，家疾全員のふと ん在管理する主婦の立場加られれ゙，取り扱いやすさが ふとんへの要求の中で，大きなウエィトを占めていて当 然といえる。

そこで,こういった暮らしの中からの要求借つき， ふとんに対する好みと日頃の取り扱いやすさから，(1) 綿化要着をるっている人，(2)措ふとんは軽い方が好き

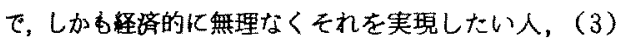
天旰しなどの日常管理を楽にしたい人，(4)収納スぺ 一スの関係加所有效数を少なくしたい人，の4つの夕 イプを考えたるしてさらに，それぞれの要求を満たす ふとんの素村を選択し，それらの効果的な用い方を，室 温伈した組み合わせパターンとして图6にまとめた。

蚁適な眠りを得るためには、精神的な疲労やストレス がないとと，寝室の温度や湿度，騷音，照明といった環 境条件が満たされているととに加えて，室温の変化に応 した薑切なふとんの組み合わせがなされていなりれれ゙な らないるをしてさらに，そてで用いられるふとんは，保 温生や吸・透・放湿性といった要求性能を满たしている
だけではなく，使う人の好みや習慣・ライフスタイルに あっている必要がある。したがって，現代生活にふさわ しい“快適なねごてちを得るための寝具の条件”を満た すためには，まず，それぞれの好みやライフスタイルに 応し，優先すべきすのを明確にしてふとんを選択し，そ れらの性能を理解した上で，室温に応じたふとんの組み 合わせを決定する必要があるといえる。

\section{引用文献}

1) 前川泰次郎，「寝具用類（ふとんわた，子とん地， カバー.シーツ)に要求される性能」，䄉維慜品消 費科学 Vol. 25, No. 1，20, 1984

2）小原二郎・小川光暘，『寝具の歴史と科学』、(株) キャップロール

3）今井京子・宮沢モリエ・梁頼度子他，「夏季の睡眠 環境の漫床気候・睡眠経過におよほすす影響」，家政 学研究 Vol. 26, No. 1, 1979

4）西村和代，「カーテン一その遮光性と遮熱性の研 究」, 商品科学研究所 CORE 37, Vol.11, No. 3 1984

5）南本珠己・八島直子・太田俊子，「変わりつつある ふとんライフ」, 商品科学研究所 CORE 46, Vol. 13, No. 4, 1986

6）久野寧, 『汗の話』，光生館

7）全日本わた德装品製造協同組合，『寝具についての 消費者アンケート調査』1984

8) 商品科学研究所, Two way 64 号

9) 商品科学研究所, Two way 30 号

10）商品科学研究所. Two way 75 号

11）宮沢もリ工他，「季節に上る锓床気候之睡眠経過の 関保について」，家政学研究 Vol. 21, No.1, 1974

12）商品科学研究所, Two way 56 号

13）原田隆司，「衣服内気候の科学亡衣生活」，䄉維慗 品消費科学 Vol. 27, No. 5, 200, 1986

(昭和 62 年 2 月 21 日受理) 